eCommons@AKU

Book Chapters

January 2006

\title{
Challenges to education in Tajikistan: The need for research-based solutions
}

\author{
Sarfaroz Niyozov \\ Aga Khan University, sarfaroz.niyozov@aku.edu \\ Stephen Bahry \\ University of Toronto, Canada
}

Follow this and additional works at: http://ecommons.aku.edu/book_chapters

Part of the Curriculum and Instruction Commons, Curriculum and Social Inquiry Commons, Educational Assessment, Evaluation, and Research Commons, International and Comparative Education Commons, Other Educational Administration and Supervision Commons, and the Other Teacher Education and Professional Development Commons

\section{Recommended Citation}

Niyozov, S., \& Stephen, B. (2006). Challenges to education in Tajikistan: The need for research-based solutions. In J. Earnest \& D. F. Treagust (Eds.), Education reform in societies in transition: International perspectives (pp. 211-231). Rotterdam: Sense Publishers. 


\section{CHALLENGES TO EDUCATION IN TAJIKISTAN: THE NEED FOR RESEARCH-BASED SOLUTIONS}

\section{ABSTRACT}

Education in Tajikistan today is acknowledged by the Ministry of Education ofthe Republic of Tajikistan and by international agencies as facing manychallenges. Infrastructure and materials need replacement or repair; curriculum needs to be adapted to changing conditions; professionaldevelopment for teachers is required, while means to retain experiencedteachers and attract new ones need to be found. At the same time, childrens'meaningful access to education has been threatened by various factors thatreduce their attendance and participation in education, keeping some youth outof school altogether. This chapter argues that research in education in Tajikistan and the development of research capacity throughout the educationalsystem is one of the prerequisites for improving the education of youth inTajikistan. The chapter outlines Soviet educational research traditions andthe systematic centralization of curriculum development and research duringSoviet times outside the republic and the resultant local underdevelopment of curriculum development andeducational research capacity on independence. Educators in Tajikistan today are influenced by inherited and new ideas on curriculum, pedagogy, teacher training, textbooks and assessment, and analyzes documents issued by the Ministry of Education and the World Bank to identify current discourses on the education system's needs. Nevertheless, there is still insufficient knowledge about the current state of education inTajikistan, and a lack of information about the attitudes of all stakeholderstowards educational change. The chapter cites recent field work on the lives and work of teachers in the field as an example of how practitioners'experience is both in accord and discord with views of both the Ministry ofEducation and external educational development agencies, and suggests thateffective long-term development of education in Tajikistan needs moregrounding in qualitative and quantitative research, and a greaterdevelopment of local research capacity at all levels of the educational system. 
Tajikistan is a landlocked country of six million people. Constructed as a Soviet republic between 1924-1929, it emerged from the ruins of the collapsed Soviet Union in 1991. Tajikistan's transition from a Soviet quasi-state to an independent state is still in process. Its experience of nation building, economic and cultural renewal and social cohesion have been more dramatic and traumatic than that of the other Soviet states. During Soviet delimitation in 1920s, Tajiks believe to have lost Samarqand and Bukhara, their major cultural centres to Uzbek USSR; subsequently, they inherited the poorest and least developed mountainous part of the former Bukhara and Kokand emirates (Haugen, 2003, pp.138-149; Masov, 1996). During the Soviet years, the country received an uneven degree of attention from the centre, which resulted in its disproportional development, where the northern parts turned into prosperous modernised economic zones and the south remained rural, underdeveloped and traditional society. This heightened the already manufactured regional rivalry among Tajiks (Akiner, 2001). Nor did Tajikistan manage to complete the creation of a unified nation during the Soviet period (Roy, 2000). All these historical precedents (e.g., religious differences predating the Soviet period; a territory defined by seemingly arbitrary borders decided in the 1920 s resulting in an underdeveloped sense of nationhood and asymmetrical development during Socialist modernisation), added to the intervention of regional and global forces, led to a civil war that not only ruined the country's fragile economic basis, but also seriously threatened its existence as a whole. This tide of destructive trends began to halt in 1997, when a peace deal was brokered between warring factions of the Tajik conflict. Since then the country has been undergoing economic and cultural recovery and revival.

\section{The Challenge of Studying Education in Transition in Tajikistan}

Writing a short article on the challenges to any education in transition is a naturally daunting task, given that every aspect of the system is in flux. In the case of a country such as Tajikistan, this is even more challenging because of two major structural reasons. The first is a weakness in research capacity: there is a dearth of reliable and valid data due to the underdeveloped research tradition in Tajikistan, the lack of research facilities, critical scholarship and the confidence to share research data for identifying solutions to the problems (OSI, 2002). The second relates to teachers, curriculum and teaching materials. This chapter attempts to address these two major issues and show their implications for research, training and policy of transition. Transition is not a problem only; it is also an opportunity to lay a sound foundation for an effective educational future. The chapter consists of an introduction to the context of education in Tajikistan, a brief discussion of some of the major challenges of education and a conclusion. The chapter's emphasis is not on repeating the state and donor-centreed perspectives mentioned above, but to illustrate how these are articulated by people involved in educational provision. 


\section{Underdeveloped Research Tradition in Tajikistan}

While general levels of education rose in the Tadzhik SSR under the Soviet Union, and approached levels in the Russian SFSR and the other Central Asian states, the record for graduate education was less impressive. While in 1971, the central Academy of Sciences of the USSR employed 3,044 members with Doctor of Science, and 15,174 with Candidate of Science degrees, the Academy of Sciences of the Tadzhik SSR employed 347 members with Candidate of Science degrees, and only 35 with the Doctor of Science degree (Statistika, 1972).

As a result, in the Soviet era, advanced research on education, curriculum policy discussion and textbook preparation were for the most part done in Moscow, where most specialists with advanced degrees in pedagogy and academic disciplines were located. Thus, the research capacity in education, as in all fields in the Tadzhik SSR was relatively underdeveloped for the population of the republic. Curricula used in the Tadzhik SSR were largely identical to those developed in Russian for the Russian SFSR.

At the same time, Soviet-era scholarship has been criticised for its highlypoliticised backdrop and reductionist projections (Brigel, 1996). Educational research was possibly the least developed area formally guided by behavioral psychology and Marxist-Leninist positivist epistemology exhibited in the form of quantitative statistical analyses and quantified sociological surveys, aimed at proving and verifying Soviet educational theories and models (Tillet, 1969). The pages of the local teachers' periodicals such as journal of Maktabi Soweti (Soviet School) and paper of Gazetai Muallimon (Teachers' Gazette), translate.' directives of the communist party and presented examples of best practice through opinion papers of the best teachers. These voices, though important, were filtered so as to avoid controversy, complexity, and contradictions of the Party directives. This trend at filtering and selective use of data has continued in post-Soviet times (OSI, 2002; ICG, 2003a).

The post-Soviet period revealed lack of skills in policy-making, ineffective information management and non-participatory governance as the major hurdles to moving Tajikistan's education system out of its current malaise (OSI, 2002; ICG, 2003 a \& b; WB, 2003). Such shortcomings are mentioned frequently by external Non Government Organisations (NGOs) without an analysis of the internal Soviet debate on education or of the systemic factors leading to them (Landa, 1975; Skatkin \& Kraevskii, 1981; Lysenkova, Shatalov, Volkov, et al., 1986). Considering the challenges to educational research in Tajikistan and its legacy of educational research, the current chapter treats some of the above mentioned data cautiously and builds on the post-Soviet research activities that stem from western sources and NGOs funded by international donors (Kuder, 1996; AKF, 2001; UNDP, 2000; WB, 1999). Largely based on surveys, group discussions and statistical data, and geared towards the needs, interests and preconceptions of donors and the international community, and led by comparative methods, the majority of these reports illustrate general trends and directions in education, leaving out depth, complexity, issues and challenges that usually emerge from theorising and discussions based on qualitative studies (Aliberdieva, 2002; 
Niyozov, 2001, 2004).which we supplement in this paper with the analysis of additional qualitative studies

The pre-perestroika Curriculum legacy has led to a shortage of mature senior researchers in the field of education who are holders of a degree in education higher than the candidates' level and are based in Tajikistan. Secondly, there is no institution in the Republic of Tajikistan that grants doctoral degrees in education and can prepare the next generation of educational researchers and play a leading role in independent research on educational policy. Thirdly, these two shortages may lead to a continued dependence on outside expertise and research agendas in the formation of education policy. Fourthly, language policy in education has reproduced Soviet policy with national schools preserved along ethno-linguistic lines, with Tajik replacing Russian as the dominant language. Finally, policy makers may seek for solutions to current education dilemmas from known policy options that have been debated and even attempted in Soviet education. As an example, the government recommends that schools in Tajikistan engage in agricultural activity involving children, for example, in the gathering of medicinal herbs for sale (UNESCO, 1999). Though largely inspired by the current financial crisis, such policies harken back to Soviet curriculum theory, which emphasised unity of theory and practice, and the application of study to labour, sometimes requiring children to learn practical skills in keeping class garden plots (Holmes, Read \& Voskresenskaya, 1995).

\section{EDUCATION}

Literacy among Tajiks was around $4 \%$ for men and $0.1 \%$ for women in the preSoviet times (USDoS, 1996; Khan, 2003). Soviet social policies created a modern education system, with extensive infrastructure. However, some think Soviet modernisation was not simply based on Marxist egalitarianism and its antiimperialist premises of freedom, equality and opportunity, but aimed at simultaneously promoting a Russian colonial agenda (Belkanov, 1997).

Regardless, Tajikistan enjoyed relatively comfortable educational achievements compared to most other Asian countries, with much higher school enrolments than India and Iran (Medlin, Cave \& Carpenter, 1972), and a higher proportion of the population enrolled in higher education than in Japan (Statistika, 1972). One teacher summarises the Soviet accomplishment in Tajikistan as follows:

We [as teachers] work so that the children live better than we do and our community does not fall back to the level of Afghanistan. In 70 years we have moved so much ahead and we do not want our people to become ignorant again (Niyozov, 2001, p. 52).

Thus, the post-Soviet educational situation is seen as almost tragic in comparison. Reports highlight that Tajikistan may be the world's only country where children lag behind their parents in attaining education (ICG, 2003b; OSI, 2002, 2003). The country is facing enormous challenges to maintain its educational infrastructure, achievements in the fields of literacy, access and equity, let alone its 
modernisation. The number of challenges is enormous, with each deserving a separate analytical paper. The rest of the chapter will spell out some of the most important post-Soviet challenges. The chapter will also show how these challenges are constructed socio-historically, politically and systematically. Without considering context, it may not be possible to find sustainable and relevant solutions.

\section{Governance of Education}

In Soviet times, education was governed by the Communist party (which embodied state) in a total sense (Heyneman, 1998). All aspects of education were planned, financed, managed, delivered and assessed by state organs. Such an approach was based on the Soviet socialist modernisation theory whereby the state was seen as a major tool for effecting change and education was considered as a powerful hegemonic tool for the legitimisation of the Soviet state and communist party. This approach resulted in the rapid expansion of the educational infrastructure with the literacy rate reaching $99 \%$ in the 1980 s and relative equity of access and opportunity. Yet the educational system was rigidly politicised and bureaucratised, which led to the stifling of diversity, competition and creativity. The single Marxist-Leninist truth, however also subsumed Russification, causing neglect in education of local history, culture and identity in Tajik S.S.R.. A history teacher highlighted these issues:

During Soviet times History of Tajikistan was a small section within History of the USSR. In fact, we studied the History of Russia from the primitive time until the present. Soviet we said, but Russia's history we taught. It was perhaps acceptable, because we were united within the Soviet Union. But it was not right to ignore our own history, the history of a whole nation, even at that time. I think our Tajik scholars did not pay enough attention to it (Niyozov, 2001, p. 219).

Centralised governance was relaxed when Gorbachev introduced policies of Perestroika (Restructuring) and Glasnost (Openness) from 1986-1991, which relaxed the Party's total grip over peoples' life and work, called for alternative approaches and cultural and structural changes within the existing system. Some degree of governance including administration, financing and control was devolved to the republics, regions and even villages where most Tajik schools are located. This resulted in greater freedom on the teachers' part in terms of curriculum delivery and relations among the school staff. One teacher put it:

My lessons became freer. We could discuss issues of life with great excitement. No one could tell us to teach his or her way. All the teachers were excited about the flow of news.

In Tajikistan, as in other Central Asian states, the process of democratisation and grass root participation soon began to pull back after independence (Gleason, 2004). The government increasingly tightened its control by returning to the 
traditional (i.e., pre-Soviet), and Soviet-tested top-down (pre-Perestroika) measures, which included centralised control of curriculum content, the examination system and appointment of the loyal school and district board heads.

At the same time, fiscal responsibilities were devolved to the regions and schools. Given the total collapse of tax collection and public expenditure, the regional administrations had become bankrupt and the financial burden of school maintenance, provision of textbooks and even teachers' salaries were laid upon local schools and communities. The distinction between not-for-profit and forprofit educational institutions has been blurred. Decentralised financing of textbooks, for example, is accepted as necessary for some time to come due to the state's extreme financial weakness. Lack of resources for textbooks is seen more as a consequence of the economic crisis than as a systemic problem in management methods. Lack of books, for example, is blamed partly on difficulties in getting paper, as well as on inefficiency of central parastatal publishing houses (UNESCO, 1999).

Such tightened control over the administration, and the increase of pressure, juxtaposed with the inability to provide financial backing, has led to a number of precarious outcomes such as demoralised teachers', staff reductions, worn-out infrastructure, closed schools, reduced attendance and schools' elicitation of money from parents by various means, including extrajudicial ones (e.g., in the forms of misuse of official position, accepting gifts, donations, bribes for selling certificates, increasing students' final examination grades and unfair distribution of university placement quotas (ICG, 2003a). Corruption, rife in later Soviet years, tightened its grip over post-Soviet education that most teachers were disgusted. In the words of one teacher:

Imagine a poor child prepares himself all life, works day and night. Then someone else who had enjoyed all life gets to the university by giving a bribe or using a connection. I have developed hatred for those who do all this. I feel humiliated and slapped in face. ... When you see your good student has failed you curse the earth and the sky (Niyozov, 2001, p. 302).

Though public in name, most schools now charge fees and accept donations from people with doubtful backgrounds (OSI, 2002; ICG, 2003 a \& b). This situation presents teachers with a dilemma:

It is hard to explain to children that drugs and guns are temporary. The boys reply that these activities provide food, clothes, jobs, cars and even better education than the school. With dollars in hand, they can hire tutors, buy diplomas of whatever specialty you want. There are homes with five to seven cars, and some of them are foreign-made (Niyozov, 2001, p. 240).

Another teacher pointed out the implications of corruption and the role of education in its resolution:

If corruption continues like this, things may not improve at all... The change will come only if people with a conscience, with a balance of ethics and 
knowledge are up there. These are people who could say no to their own desires and think about others.

Schooling is thus clearly implicated in increasing social divisions based on wealth, connections and class, since a quality education is only available to members of the financial and political elite who can pay for it. Education has become a commodity to be bought and sold; its image as a public good and human right tarnished. A parent, unable to afford the fee-paying school, pointed out that, "our children in the general stream have no hopes, except to become farmers, shepherds and drivers" (Niyozov, 2001, p. 213). Another teacher worried about the implications of the commercialisation of education:

I agree that the lyceum and profiling help the gifted students get ahead. But why are we worried about the gifted ones and not worried about the weaker ones? I get more worried about those students that are left behind. ... I have talked about this, but no one listens to me (Niyozov, 2001, p. 248).

In Soviet times, the heads of village schools were far more than headmasters: they were involved in leadership of almost all social, cultural, educational matters in their schools and villages, such as resolving village disputes and even preparing fodder for collective farm cattle. The school head's role was as much political as educational, including duties such as local supervision of anti-religious campaigns and ensuring the undisputed loyalty of teachers to the party line; yet not all heads acted merely as tools of the Party/State (Niyozov, 2001).

Further, changes came with Perestroika and the Soviet collapse. For a time, teachers could select their own heads and strike for better conditions. In one case, the head took the teachers' side and was punished: his salary was not increased, he was not given a chance to visit his sick daughter, and he was deprived of a rightly deserved service title (Niyozov, 2001). A teacher from the school described the situation as follows:

The higher authorities got scared of our unity and wanted to transfer us to various schools so as to break us. They threatened all kinds of punishments. Our head was taken to court because he openly took our sided during the strike. We all could leave teaching. That would have been much easier for us. It would have also been a big blow to those who wanted to punish us. But we worked for the sake of the children and the community, not for the sake of the government officials (Niyozov, 2001, p.224).

As in Soviet times, loyalty is still a major criterion for the appointment of school heads although the object of their loyalty has changed, but otherwise little has changed: they are expected to carry out state directives. A deputy head expressed the continued complacency of headmasters during a meeting on streaming of schools:

Our school heads speak like Brezhnev, as if they are in a session of the Congress of the Communist party. Everyone supports the idea because it is fashionable. Some heads said streaming is the demand of the time and market 
economy. I honestly do not know how streaming is connected to the demands of the time, democracy and a market economy (Niyozov, p. 249)

Similarly, inspectors and other education officials have largely recovered their former unsupportive approach to teachers:

Unfortunately, the majority of the inspectors would point out what is missing and why I have not taught the way I planned or the way it is agreed upon. The inspectors were also concerned with the academic side of the lesson only. It was a nervous process to meet with them after the lessons. Now, no inspector has any right to demand from me anything for this miserable salary. (Niyozov, 2001, p. 198).

With the collapse of the one-party monopoly over education, the increasing numbers of stakeholders with often contradicting demands and pressures have added to the confusion:

During the Soviet times, we had a clearly defined direction: to serve what the party and state said. Now anyone who is not lazy shouts at us: the state authorities demand of us to follow what they say; parents criticise us and tell us how to teach; international organisations ask us all kinds of questions, listen to us, nod and go (Niyozov, 2001, p. 228).

Similarly the approach to change has continued the old way:

The reformers are concerned about showing that they are making many changes, not how and what the students learn. Like the Soviet times, they want to report that they have changed this and that. That this has become more and that has increased. The students have become like experimental mice As a result, the students complete grade 11 and are confused. Next, how can we reform history with no salaries, no textbooks, cold classes and hungry kids? Our reform is again coming from the top, "you must do it". No one listens to teachers. In our school we have so many reform ideas but we have no support and resources to put them into practice (Niyozov, 2001, p. 249).

\section{Teacher Factor}

It has almost become axiomatic that no education reform can succeed without a good teaching force. In Soviet times, the question of human resources and school personnel was projected as resolved once and for all. Schools were so overstaffed that the student-teacher ratio fell to 8-10. Teachers were provided with comparatively high salaries, free power and housing, subsidised fuel, visits to sanatoriums, free subscriptions to periodicals and professional development opportunities. Some teachers believed that, like Communist ideology, the teacher's status was also unshakable. A female teacher explained this as follows:

We [women teachers] were in the centre of the society, and led other women. They came to us for everything, from consultation on women's health to 
borrowing money. As a woman teacher we got good money and a higher education compared with the majority of women who were housewives and sovkhoz (state farm) workers. Unlike them, we can argue and talk openly with men other than our husbands. It is still more or less like this (Niyozov, 2001, p.238).

A teacher compared the post-Soviet conditions with those of the Soviet in the following manner:

During Soviet times I had many opportunities to study and teach any subject I was supposed to. I knew all that I was to teach by heart. Sometimes I would teach even without a written lesson plan. Nowadays, I have to look, read and search for everything new, but I cannot find material and information to teach properly. I do not know whether what we teach is right and whether this will be enough for the students to pass the history entrance exams to the University. Last year we fought with the examiners at the Khorog State University. I told them they should know what we teach and develop exam tickets on this basis, instead of asking students about things they have never studied and subsequently failing them (Niyozov, 2001, p. 176).

Another teacher, however, revealed that the professional development courses were not that effective:

The instructors forced us to take notes of their boring and monotonous lectures. ... During the exams we just re-told the content of their lectures, if we wanted good grades. Even during the seminars only a few students would come forward and read their notes to the rest of class. Neither discussion nor questions were encouraged (Niyozov, 2001, p146).

While teachers' were kept very busy in the Soviet times, those pressures were ameliorated with support structures, so teachers largely accepted the situation:

We did dozens of other unpaid jobs. But we did not complain much: when a state feeds you and provides you with honour and status, why don't you work for it? Because our life conditions have worsened, we are busier now than ever before. We do not know what will await us tomorrow. We work day and night yet we are totally dependent on others (Niyozov, 2001, p. 243).

Ironically, on paper, almost every thing has remained the same in post-Soviet Tajikistan. But in reality, teachers have become the most impoverished people in the society. One teacher expressed the change:

People said that from a teacher's home "oily smoke" comes out. Teachers were cleaner, better dressed, richer than the leaders of the district, seemingly worked shorter days and were always at the centre of attention. Their work was not boring either... However, by the time I finished my studies at the Institute, returned from the Army and settled down [that is 1990], everything 
had become bad and being a teacher became the worst thing in the area (Niyozov, 2001, p. 147).

Table I shows how intensified the life of a rural teacher has become in post-Soviet Tajikistan.

Table 1: Changes and increased responsibilities of the life of a rural teacher

\begin{tabular}{|c|c|}
\hline Domains & Changed and/or Increased Responsibilities \\
\hline 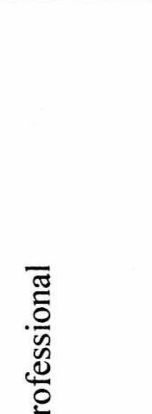 & $\begin{array}{l}\text { Guide students about politicians } \\
\text { Curriculum developer; find gaps in curriculum and rectify them; } \\
\text { critique reform ideas } \\
\text { Defender of students against abusive parents } \\
\text { Fighter for them with the university instructors } \\
\text { Researcher for new materials to supplement lack of textbooks } \\
\text { Filling in for teachers who have left the profession, even in } \\
\text { different subject areas } \\
\text { Offering private tutoring contrary to state regulations to help } \\
\text { students raise graduating grades }\end{array}$ \\
\hline 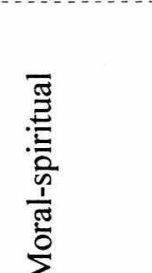 & $\begin{array}{l}\text { Attendant and performer of religious ceremonies } \\
\text { Defender of community and of religious authority } \\
\text { Teach students to share food and clothes } \\
\text { Writer of articles in defense of one's religion } \\
\text { Guide students and community in resistance to drugs, violence, } \\
\text { and gun culture }\end{array}$ \\
\hline 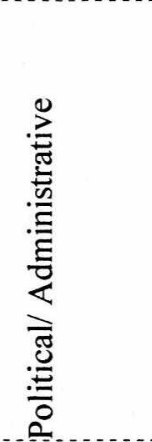 & $\begin{array}{l}\text { Peace maker between Tajiks and Kyrgyz and between Tajiks of } \\
\text { different regions } \\
\text { Participant in strike } \\
\text { Warn students and community about corrupt politicians } \\
\text { Curriculum and materials developers } \\
\text { Local representative of state primarily responsible for conductor } \\
\text { of census, referendum and elections } \\
\text { Raising funds for the school } \\
\text { Administering textbook rental schemes } \\
\text { Leading Parent-Teacher Associations }\end{array}$ \\
\hline 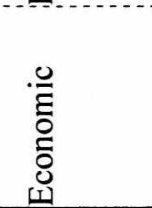 & $\begin{array}{l}\text { Seller in the market } \\
\text { Labourer for the rich } \\
\text { Kommersants (petty-traders; } \\
\text { Subsistence Farmers }\end{array}$ \\
\hline
\end{tabular}


Ten years from independence, teaching in Tajikistan remains the lowest status profession, an increasingly feminised, poorly paid, and thankless job. Many teachers are demoralised, as the following voice put it:

Even though I am very busy with handling my survival needs, ... I could daily put 3-4 hours into preparation for teaching. But why? Who needs my teaching? When positions are bribed and diplomas are bought? When the school authorities say to the students and teachers: "If you do not want to come to school, to the devil with you." When there is misuse of the school's property. When the sons of the leaders of the village stop their peers from coming to the school. When some people at the rayono [District Education Board] say they don't care whether our children get education (Niyozov, 2001, p. 371).

\section{Curricula and Textbooks}

Due to the Soviet legacy where a unified curriculum was largely designed and approved in Moscow and subsequently downloaded to republics for translation and implementation, with only curriculum in subjects such as local language and history designed by local experts and where the textbooks were provided almost free of charge, the current Tajik education establishment suffers not only from the absence of proper textbooks and learning materials, but also from the irrelevance and even more, from a lack of skills and knowledge in curriculum development. Reports by external NGOs, such as OSI (Open Society Institute), AKF (Aga Khan Foundation), and ICG (International Crisis Group) reports, as well as a number of internal Soviet educationalists (Landa, 1975; Skatkin \& Kraevskii, 1981) indicate that curriculum was understood as list of subjects to be taught rather than a concept based on principles and objectives.

\section{Pre-perestroika Soviet Curriculum and the Legacy in Tajikistan}

A review of literature on the history of development and reform of curriculum reveals a more complex situation. Soviet ideas on curriculum were not simply Marxist, but synthesised diverse streams of thought. Soviet education continued the tsarist Russian encyclopedic concept of curriculum derived from the European enlightenment, with an egalitarian provision of this curriculum to all rather than only to the children of the élite. Under the influence of Marxist philosophy, Soviet psychology, and Dewey's American educational progressivism, educators felt that all children, regardless of family background, were equally able to learn such challenging curricula if the state provided the proper conditions. Thus, a unified curriculum was delivered in comprehensive schools without streaming by ability. In Marxist thought as well, effective learning was felt to combine theory with practice, study with labour, and take place collectively. Thus, at times polytechnical education, where students could work voluntarily, develop vocational skills, and apply learning in practice, has been emphasised. Table II below displays some of the key ideals for the development and provision of 
curriculum in the USSR before Perestroika that have been identified (Danilchenko, 1993; Holmes, Read \& Voskresenskaya, 1995; Ivic, 1994; Skatkin \& Cov'janov, 1994; Sutherland, 1999).

Several strains of thought on curriculum have co-existed over the years in Soviet education, with inevitable curriculum reforms when one strain has been overemphasised at the expense of another, or the perceived needs of the state and society have changed. In practice, polytechnical education and the provision of a unified encyclopedic curriculum for all has been difficult to implement, especially after compulsory secondary education was extended to 10 years (Holmes, Read \& Voskresenskaya, 1995; Sutherland, 1999).

Table 2: Soviet ideals for education before Perestroika (1970s-1986)

Absolute priority of State Implementation

Priority of Central over Republican over Provincial authority

Bureaucratic Determination and Administration of Education Policy

Equality of Learning through Uniformity of Curriculum throughout USSR

Equality of Funding through Central Financing

Despite theoretical experts at the centre, one shortcoming in curriculum development was inadequate consultation with subject teachers and other experts. As a result, curricula contained excessive information, introduced some topics too soon, and were often poorly sequenced. Curriculum guides gave teachers and inspectors no guidance about what could be dropped if time was insufficient, leading inevitably to pressure on teachers to cover all points equally, and thus overwhelming students (Skatkin \& Kraevskii, 1981).

For Russian residents of the Tadzhik SSR and those wishing to have the advantages of a Russian-medium education, in fact, the curricula and textbooks were identical. For those attending the national schools, that is, Tajik-medium school for ethnic Tajiks, Uzbek-medium school for ethnic Uzbeks, and Kyrgyzmedium school for ethnic Kyrgyz, all curricula and textbooks were translated from Russian curricula and textbooks, except for courses in national languages and literature. Curricula and textbooks for Tajik language and literature were developed and printed in Tadzhik SSR by local experts, while those for Uzbek- and Kyrgyz-medium schools were imported from the Uzbek SSR and Kyrgyz SSR (Lewis, 1973; Landau \& Kellner-Heinkele, 2001). As a result, curriculum and textbook development in the republics of the USSR was largely a matter of implementing decisions made elsewhere. 
With the advent of Glasnost' (Openness) and Perestroika (Reconstruction), increased diversity of voices were heard in educational debate. True, individual researchers had raised questions previously about how to improve education, and many isolated educators attempted innovative solutions to such problems in the field, yet sharing of these criticisms and ideas had been restricted until, during Perestroika, debate was opened on how to achieve greater balance between: central and local control over education; standardisation and diversity in the curriculum; mastery of knowledge and its creative application; the place of Russian and other languages of the USSR; teacher-centred and student-centred methodology; rural and urban education and advantaged and disadvantaged areas. Reforms on most of these questions were proposed, some introduced, but few implemented successfully before the collapse of the Soviet Union in 1991. Democratisation and decentralisation of decision-making with authority shared between Union, Republic, Province and school were proposed to guarantee appropriate international, national and regional content of curricula, including increased roles of republican languages in education. Shortages of existing textbooks were reported, but also lack of textbooks due to sudden politically-motivated curricular changes. History textbooks were withdrawn in 1989, before new ones were produced, leaving teachers without textbooks. Table III displays key ideals affecting curriculum development and textbook provision during Perestroika (Skatkin \& Kraevskii, 1981; Holmes, Read \& Voskresenskaya, 1995; Sutherland, 1999).

Table 3: Soviet ideals for education during Perestroika (1986-1991)

Continued Priority of State Implementation

Increased Equality of Authority among levels of government Increased Equality of Learning through Differentiation of Curriculum Shared Democratic and Bureaucratic Determination of Education Policy Continued Bureaucratic Administration of Education Policy Continued Funding through Central Financing

Glasnost in education led to increasing questioning of curricula and pedagogy from both top and bottom. Senior academics in the pedagogical field such as Skatkin and Kraevskii (1981) critiqued the development of curricula with insufficient grounding in pedagogical and psychological research, consultation with teachers and testing in the field. Innovative teachers were also encouraged to share their approaches to adapting standard curricula and textbooks in educational periodicals, with the most famous example being the "Pedagogy of Cooperation" developed by a group of "Teacher Innovators" (Lysenkova, Shatalov, Volkov, et al, 1986). 
However, apart from a few islands of innovation (e.g. Azimov's experimental school in northern Tadzhik SSR), the ensuing debate in the Tadzhik SSR centred mainly on increasing the importance in the life of the republic of the Tajik language and cultural heritage, leaving little room for debate on other aspects of education (Akbarzadeh, 1996; Schlyter, 1998 \& 2001; Landau \& Kellner-Heinkele, 2001).

\section{Curriculum in Tajikistan since Independence}

An examination of the report prepared by the Tajikistan government on Education for All submitted to UNESCO (1999) highlights the following themes (see table IV below) related to needs for curriculum development and textbook provision in order of priority based on the value-laden language contained in the report.

Table 4: Ministry of Education priorities identified for textbook provision in Tajikistan

\begin{tabular}{ll}
\hline Priority & Theme \\
\hline 1 & Absolute Insufficient Number of Textbooks \\
2 & Affordability of Textbooks for Families \\
3 & Preparation of Textbooks in Tajik and other Languages \\
4 & Preparation of Textbooks in the Humanities \\
5 & Changes in Curriculum Aims, Content and Pedagogy \\
6 & Changes in Management and Financing \\
7 & Changes in Teacher Knowledge and Teaching Methods
\end{tabular}

Below we shall briefly explain the implications of each of the seven concerns. Absolute Insufficient Number of Textbooks contributes to a fall in the general literacy of youth, and risks children of the poor, street children and orphans growing up as a "lost generation" without even the most basic skills previously acquired in Tajikistan (UNESCO, 1999; ICG, 2003a \& b).

Teachers with insufficient textbooks have adapted the curriculum and their pedagogy to reflect what they feel can and should be taught with the resources available, which is an amalgam of Soviet and post-Soviet curricula, often using the conspectus or teacher-prepared summary of the most important material on the blackboard (Niyozov, 2001). This is an approach favoured in the Pedagogy of Cooperation (Lysenkova at al., 1986), which obliges teachers to simplify overloaded curricula, by establishing criteria for themselves to distinguish essential subject matter from unessential detail, and material at an appropriate level of difficulty from material that is too complex for the students (Skatkin \& Kraevskii, 1981), which effectively turns the best teachers into curriculum makers (Clandinin \& Connelly, 1992).

Affordability of Textbooks presents a contradiction between the constitutional commitment to free education for all and the state's inability to provide free 
textbooks sufficiently. Textbook costs have been downloaded to families, and textbook fee subsidies for poor families have been more discussed than implemented, leading to asymmetrical access to the few textbooks that exist. Research is needed on the affect of rental charges for textbooks on children's access to textbooks, achievement and development of functional literacy.

Preparation of Textbooks in Tajik and Other Languages, such as Uzbek, Russian, Kyrgyz, a task that was formerly done outside Tajikistan, and in East Iranian minority languages of Tajiks. The government has expressed a need for professional development in this area, via experts from the "near abroad" (Former Soviet Union) emulating Russian experience (UNESCO, 1999).

Preparation of Textbooks in the Humanities and other subjects related to history, culture and the spiritual legacy of the peoples of Tajikistan depends on research and professional debate about the role of history, literature and religion in the curriculum. Second, the decision about which of the current competing visions of Tajik identity (i.e., civic versus ethnic identity) will be promoted through textbooks has important implications for Tajikistan's citizens in terms of their internal social cohesion and their participation in an increasingly globalised world. This decision will also have an impact on the content of textbooks in languages of the minorities of Tajikistan, and on relations with neighbours in the region.

Changes in Course Objectives and Pedagogy have been recommended to place less emphasis on memorisation of facts and to pay more attention to developing creativity and problem-solving skills that can be applied outside school. The Tajikistan government expresses great confidence in the knowledge, ability and judgment of teachers to adapt to these changes (UNESCO, 1999). For such changes to be more sustainable, they should, in addition to borrowing from Western research, build on those innovative approaches developed in the Soviet era(Landa, 1975; Lysenkova et al., 1986; Skatkin \& Kraevskii, 1981) and postSoviet times (Niyozov, 2001).

\section{CONCLUSIONS AND IMPLICATIONS}

The consequences of the above discussion, which touches on only a few of the challenges for educational research and practice in contemporary Tajikistan, are several. First, there is a shortage of skilled researchers, research centres, and conditions conducive for researching and knowledge dissemination in Tajikistan. Without major developments in these areas Tajikistan may remain dependent on outside expertise in the formation of education policy, curriculum and textbooks development. As a result, there is insufficient reliable, valid information, whether quantitative or qualitative, for education for fully informed decisions on policy and practice.

Second, there is a need for open access to information for policymakers and practitioners, and journals and other fora where research and opinions on policy and practice can be shared widely. The perestroika era educational debate calling for increased openness and participation in education was cut short in Tadzhik SSR by the collapse of the USSR and the civil war and had little time to have an impact. 
Individual members of the system have been innovative, even in rural areas. Despite such examples of innovations in education in Tajikistan and the former Soviet Uninion in general, innovativeness has been isolated, and not institutionalised. Relevant and sustainable curriculum reform would require research on effective local innovative practices of teachers in adapting curricula and materials to the concrete challenges at the local level, and disseminating these practices rather than simply emulating practices imported from elsewhere (Farrell, 2002; Hopkins, 2002).

While policy makers may seek solutions to their current dilemmas from the history of innovations in Soviet education, they, however, must engage these previous experiences critically, i.e., whether the policies had been implemented, whether these were relevant to the realities of the republic and infer lessons from the successes and failures of such attempts. This retrospection must also be coupled with learning from the experiences of the developing countries in the region and the experiences of international education agencies. From the experience of the developed countries, for example, Tajikistan' educationalists could learn about the implications of the types of nationalism (i.e., ethnic vs civic) for the country's coping with global forces. Thus, comparative research is fundamental to countries' learning and avoidance of unnecessary experimentation, and wastage of the scare resources and facilities.

Educational administration in Tajikistan reveals a paradoxical trajectory of a return to the Soviet and pre-Soviet style where decisions are made outside and above and imposed on teachers and schools for mere implementation. Ironically few people in Tajikistan see that one of the major reasons for the Soviet collapse was the irrelevant, outdated and poorly managed education system that suffered from financial and logistic inefficiency and ineffectiveness. Unless there is a political will to democratise the governance of education, open up for debate and unless there is determination to invest in education, the already shattered Soviet achievements will be further diminished. Furthermore, lack of transparency at all levels of the education system and of reliable, valid data makes the resolution of Tajikistan's educational crisis problematic. Research needs to go beyond simple blaming of corruption and lack of finances for the system's failures; we need to engage in identifying the cultural and structural factors contributing to corruption in the education system. We need to spell out the catastrophic implications of corruption not only for education, but also for the construction of a civil society.

Yet, policies need to be designed on the basis of valid internal research, in the light of comparative experience, rather than on simple borrowing of externallybased recommendations. A World Bank review of 10 years of experience of educational reform in Eastern Europe warns against blind transfer of policies from one context to another, saying " ... it is very clear that there are no blueprints for reform. In the first place, we are facing an unusually intense and rapid experiment in state reform for which there is no precedent. Thus, it is not feasible to relate the challenges and solutions to past experiences (in the same region or elsewhere). Second, the initial conditions are quite different among the countries" (Fiszbein, 2001, p. 6). 
As Farrell and Oliveira (1993) put it:

The irony in the case of developing countries is that choices are reduced, the price of mistake is higher, and conditions for success are more limited. Yet to overcome these problems, they have to be more efficient than industrial countries have been (1993, p. 22).

Such cautions, important though they may be for Eastern Europe, are vital in the case of Tajikistan, whose "initial conditions" are the most challenging for educational reform of all the post-communist countries, and where the consequences of not basing choices on critical, field-based inquiry are potentially catastrophic. Any education reform must start with, and constantly re-address, the question of what kind of country Tajikistan should be and what kind of citizens and students would lead the country to that desired future. Carl (1999) summarised the contrast between Neoliberal and Neoconservative views of education in the table below.

Table 5: Contrasting views of education

\begin{tabular}{lll}
\hline & Neoliberal & Neoconservative \\
\hline The student & $\begin{array}{l}\text { A maximiser, a product, a } \\
\text { worker }\end{array}$ & A child \\
The parent & A consumer & A guardian \\
The teacher & A producer & An authority, a foot soldier \\
The school & A shop, a firm & A sanctuary \\
The & A variegated product of & A canon, a tradition, a set of \\
curriculum & supply and demand & common values \\
The state & A referee, a deregulator & An enforcer, a defender \\
\hline
\end{tabular}

Source: Carl (1999, p. 177)

Ideals of education of international agencies such as the World Bank $(1995,2003)$ often fall within a Neoliberal classification, while local policy makers (UNESCO, 1999), teachers (Niyozov, 2001), and parents may see schooling more in social, cultural or spiritual terms. Views expressed on education in Tajikistan (UNESCO, 1999; Niyozov, 2001) have significant differences from a Neoliberal perspective. Clearly, within Tajikistan the determination of conceptions of education is not settled. Tajikistan should find a pragmatic balance building on a variety of approaches, testing them locally and avoiding ideological dogmatism that may not conform to the present needs of the country in its move forward.

The current rhetoric concerning the centrality of teachers to the country's development must translate into practical moves in terms of selection, pre-service and in-service education, retention, salary, and other types of support. Niyozov's study (2001), for example, recommends that research be conducted on teacher development in the broadest sense, and also suggests that teachers need to be involved in policy dialogue defining the direction of education in the country, in textbook and curriculum development and governance, in order to increase the 
sustainability of education reform and of the effectiveness (Rust \& Dalin, 1990; Anderson, 2002).

Soviet understanding of curriculum as a syllabus listing topics has been critiqued extensively both internally (Skatkin \& Kraevskii, 1986) and externally (WB, 2003). Nevertheless, pedagogues, bureaucrats and researchers need practical experience in broader views of curriculum conception, implementation and evaluation. Further, knowledge and skills must be developed in textbook writing, effective classroom use of textbooks and other materials. Finally, effective policies to ensure access to quality textbooks for all must be developed (see WB, 2003).

A recent survey of educators in Russia found that, despite major activity of international NGOs in Russian education reform, “... the majority ... did not perceive these interventions as significantly having shaped the nature of the innovations that took place in the country" (Polyzoi \& Dneprov, 2002, p. 28). Tajikistan's educators may have similar attitudes, leading them to value outside partners more for their financial input than for their insight into the needs of Tajikistan's educational system. Such resistance can derive from the perception that external agencies have too little understanding of local conditions and/or too differing conceptions of education to give effective policy advice.

Nevertheless, progress is being made in deepening and broadening educational research capacity in Tajikistan. Collaborative initiatives such as Education Reform Support Unit "Pulse" (PULSE, n.d), Aga Khan Humanities Project in Dushanbe (AKHP), and Institute of Professional Development in Khorog (Background Review paper, 2001) undertaken between international NGOs and Tajikistan Ministry of Education, are steps in the right direction. These however need to go beyond statistics and surveys to qualitative studies that would reveal the complexity issues, reasons, factors and indigenous innovations and solutions.

\section{NOTES}

I According to various estimations between 20 to 100 thousands people were killed and about 1 million people became displaced. The overall damage to the country's economy stood at 20 billion US dollars.

II Tajiks are considered as one of the most ancient people of Central Asia. They constituted a part of the old Persian empires and made contributions to the Islamic dynasties since its conquest of Central Asia in 8th century (Bartold, 1927; Roy, 2000).

III During the Soviet times, the very little research on Tajik education was conducted via Institute of Pedagogical research and departments of pedagogy and psychology in Higher Education Institutions, which used to be divided into two types: Training or education institutions and research/scientific research institutions. The first type included places such as Shevchenko Pedagogical Institute, which was later renamed into Qandil Juraev's Pedagogical University in late 1980 s and the Institutes of Enhancing the Teachers' Qualification established in the capital Dushanbe and each of the four provincial centres of Tajikistan. Most of the research used to be conducted by Moscow Institute of pedagogical sciences, which had ordained the sole authority in policy recommendations, educational change and innovations across Soviet Union (Suddaby, 1989). For recent domestic research and statistics on Tajikistan education, see the website of PULSE (n.d.) http://www.ersu-pulse.by.ru/

IV Tajikistan remained a rural and agricultural country. More than $70 \%$ of its people lived in the countryside and their migration to the urban areas mainly occupied by the Russians was not 
encouraged. In the eyes of some the economy of the country remained underdeveloped intentionally to serve as a source of raw cotton for Soviet textile factories located on the Russian territories (see Fireman, 1991; Roy, 2000).

V Russian expression meaning that every one who passes by tells us what to do.

VI Ticket was an assessment tool in Soviet education. It consists of a piece of paper, usually containing three questions on a subject. Students are asked to select tickets at random and answer the questions written on it. The questions differ from one ticket to another.

VII "Oily" is a metaphor used for something that is rich, pleasant and comfortable. There are metaphors such as "oily job", "oily position."

VIII The concept of "intensification", borrowed from Larson (1980), implies (a) reduced time for relaxation during the working day, (b) reduced time for retooling one's skills and knowledge; (c) chronic and persistent overload, which reduces areas of personal discretion, (d) deprivation of involvement in curriculum planning and conceptualising, thus (e) total dependence on externallyproduced materials and expertise, and (f) reduction of the quality of service, as corners are cut to save time (Hargreaves, 1994, pp. 118-119).

IX There have been teachers in rural Tajikistan who, have attempted to apply the principles of the Pedagogy of Cooperation. For example, a teacher in Niyozov's study realized the uselessness of pursuing the officially-prescribed curriculum, began from where the students were rather than where the programme required them to be. The teacher put it as follows: "I left the programme. I said to hell with the "Parts of speech.'[required unit of instruction] I will do everything to enable these students to read and write first, if not to speak. As they start reading and writing we can move to grammar. I knew that I was violating the directives. In the journal I would write that I am covering grammar but in reality I was doing the reading intensively" (Niyozov, 2001, p. 202).

$\mathrm{X}$ As an example, the government recommends that schools in Tajikistan engage in agricultural activity as a response to the financial crises of the educational system (UNESCO, 1999). Research illustrates that such policies hearken back to Soviet curriculum theory, which has at all times emphasized unity of theory and practice and the application of study to labour, on several occasions requiring children to learn practical skills through practical activity, such as keeping class garden plots, and in the 1920 s even affiliated many schools with actual enterprises (Holmes et al., 1995).

\section{REFERENCES}

Akbarzadeh, S. (1996). Why did Nationalism fail in Tajikistan? Europe-Asia Studies, 48(7), 11051129.

Aga Khan Foundation (AKF). (2001). Background review and analysis of key issues hindering the process of educational reform in Tajikistan. A report prepared by the AKF Geneva.

AKHP (n.d). Aga Khan Humanities Project, Central Asia. Retrieved from http://www.akdn.org/humanities/Humanity.htm

Akiner, S. (2001). Tajikistan: Disintegration or Reconciliation? London: RIIA.

Aliberdieva, M. (2002). Perceived causes and consequences of drug abuse of the community of Khorog in Mountain Badakhshan autonomous province, Tajikistan. Unpublished Master's Thesis. Guelph University.

Bartold, V. (1927). Mesta Domusulmanskogo Kulta v Bukhare. (Pre-Islamic Cults Places in Bukhara). Vostochnie Zapiski, 1, 11-25.

Belkanov, N. (1997). Russian education for non-Russian people. A sample of education policy? Russian Education and Society, 39 (9), 28-43.

Brigel, Y. (1996). Notes on the study of Central Asia. In Y. Brigel. (Ed.), Papers on Inner Asia, No. 28 (pp.1-56). Bloomington, Indiana: Indiana University Press.

Carl, J. (1999). Parental choice as national policy in England and the United States. In N. McGinn \& E. Epstein (Eds.), Comparative perspectives on the role of education in democratization, part I: Transitional states and states of transition. London: Peter Lang. 
Clandinin, J., \& Connelly, M.F. (1992). Teachers as curriculum makers. In P. Jackson (Ed.), Handbook of research on curriculum (pp. 363-401). Washington, DC: AERA Publications.

Danilchenko, M.G. (1993). Pavel Petrovich Blonsky (1884-1941). Prospects: the quarterly review of comparative education, 23(1/2). Retrieved June 27, 2004, from http://www.ibe.unesco.org International/Publications/Thinkers/ThinkersPdf/blonskye.pdf

Farrell, J.P. (2002). The Aga Khan Foundation experience compared with emerging alternatives to formal schooling. In S. Anderson (Ed.), Improving as schools through teacher development: Case studies of the Aga Khan foundation projects in East Africa (pp. 247-270). Lisse, NL: Swets and Zetlinger.

Farrell, J.P. \& Oliveira, J. (Eds.). (1993). Teachers in developing countries: Improving effectiveness and managing costs. Washington, DC: The World Bank Economic Development Institute.

Fireman, W. (Ed.). (1991). Soviet Central Asia. The failed transformation. Boulder, Colorado: Westview Press.

Fiszbein, A. (Ed.). (2001). Decentralizing education in transition societies: Case studies from central and Eastern Europe. Washington, DC: The World Bank.

Ghafurov, B. (1972). Tadzhiki drevnyeishaia, drevnyaia i serednyevekovaia istoria (Tajiks: The ancient, old and new history). Moskva: Izdatel'stvo Vostochnoi Literatury.

Gleason, G. (2004). Central Asia. Ancient societies and new millennium. In S. Heyneman \& A.J. De Young (Eds.), The challenge of education in Central Asia (pp. 11-20). Connecticut: IAP.

Haugen, A. (2003). The establishment of national republics in Soviet Central Asia. New York and Hampshire: Macmillan.

Heyneman, S.P. (1998). Transition from party/state to open democracy: The role of education. International Journal of Educational Development, 18(1), 21-40.

Holmes, B., Read, G.H., \& Voskresenskaya, N. (1995). Russian education: Tradition and transition. New York: Garland Publishing Inc.

Hopkins, D. (2002). The Aga Khan Foundation school improvement initiative: an international change perspective. In S. Anderson (Ed.), Improving schools through teacher development: Case studies of the Aga Khan foundation projects in East Africa (pp. 271-296). Lisse, NL: Swets and Zetlinger.

ICG. (2003a). Tajikistan: A roadmap for development. ICG Asia Report No. 5I. Retrieved August 2, 2004, from http://www.icg.org//library/documents/report_archive/A400955_24042003.pdf

ICG. (2003b). Youth in Central Asia: Losing the new generation. ICG Asia Report No. 66. Retrieved July 25,2004 from http://www.crisisweb.org/home/index.cfm? id=2342\&l=1

Ivic, I. (1994). Lev S. Vygotsky (1896-1934). Prospects: the quarterly review of comparative education, 24(3/4). Retrieved June 27, 2004, from http://www.ibe.unesco.org/International/ Publications/Thinkers/ThinkersPdf/vygotske.pdf

Khan, S. (2003). Muslim reformist political thought: Revivalists, modernists, and free will. London and New York: Routledge Curzon.

Kuder, J. (1996). Assessment of educational situation in Gorno-Badakhshan. A report prepared by the AKF Geneva.

Landa, L.N. (1975). Umenie dumat': kak emu uchit'? Seriia pedagogiki i psikhologii, No. 4, Moscow: Znanie. (translated into English and reprinted as: The ability to think: Can it be taught? Soviet Education, March 1976, (pp. 4-66).

Landau, J.M., \& Kellner-Heinkele, B. (2001). Politics of language in the Ex-Soviet muslim states. London: Hurst and Co.

Lewis, E.G. (1973). Multilingualism in the Soviet Union: Aspects of language policy and its implementation. The Hague: Mouton Publishers.

Lysenkova, S.N., Shatalov, V.F., Volkov, I.P, Karakovskii, V.A., Shchetinin, M.P., Il'in, E.N., \& Amonashvili, S.A. (1986). Pedagogika sotrudnichestvo: otchet o vstreche uchiteleieksperimentatorov. Uchitel'skaia Gazeta, 10/18/1986, p. 2. (translated into English and reprinted as: The pedagogy of cooperation: Report on a meeting of teacher-experimenters. Soviet Education, February 1988, (pp. 82-98).

Masov, R. (1996). The history of national catastrophe. Minneapolis: University of Minneapolis. 
Medlin, W.K., Cave, W.M., \& Carpenter, F. (1971). Education and development in Central Asia. A case study on social change in Uzbekistan. Leiden: E.J. Brill.

Niyozov, S. (2001). Understanding teaching in Post-Soviet, rural mountainous Tajikistan: Case studies of teachers life and work. Unpublished Doctoral Dissertation. Ontario Institute for Studies in Education, University of Toronto.

Niyozov, S. (2004). The effects of the collapse of the USSR on teachers' lives and work in Tajikistan. In S.P Heyneman \& A.J. DeYoung (Eds.), The challenges of education in Central Asia (pp. 37-64). Greenwich, Connecticut: IAP.

OSI. (2002). Education development in Kyrgyzstan, Tajikistan and Uzbekistan. Open Society Institute Report, pp. 23-24.

OSI. (2003). Youth in Central Asia: Losing the new generation. Open Society Institute Report.

Polyzoi, E., \& Dneprov, E. (2002). Harnessing the forces of change: Educational transformation in Russia. In E. Polyzoi, M. Fullan \& J. Anchan (Eds.), Change forces in post-communist Europe: Education in transition (pp. 13-33). London: Routledge Falmer Press.

PULSE (n.d.) Website of the educational reform support unit "Pulse". Retrieved August 8, 2004, from http://www.ersu-pulse.by.ru

Rust, V.D., \& Dalin, P. (Eds.). (1990). Teachers and teaching in the developing world. New York and London: Garland Publishing Inc.

Roy, O. (2000). The new Central Asia. The creation of nations. London: IB Tauris Publishers.

Schlyter, B.N. (1998). New Language Laws in Uzbekistan. Language Problems and Language Planning, 22(2), 143-181.

Schlyter, B.N. (2001). Language policies in Central Asia. MOST Journal on Multicultural Societies, 3(2). Retrieved July 30, 2003, from http://www. unesco.org/most $/ v / 3 n 2 e d i . h t m$

Skatkin, M.N., \& Kraevskii, V.V. (1981). Soderzhanie obshchego srednego obrazovaniia: Problemy i perspektivy. Moscow: Znanie. (translated into English and reprinted as: The curriculum of general secondary education: Problems and perspectives, Soviet Education, September 1982, (pp. 6-81).

Skatkin, M.S., \& Cov'janov, G.S. (1994). Nadezhda Krupskaya (1869-1939). Prospects: the quarterly review of comparative education, 24(1/2). Retrieved June 27, 2004, from http://www.ibe.unesco.org/International/Publications/Thinkers/ThinkersPdf/krupskae.pdf

Statistika (1972). Narodnoe khoziaistvo SSSR 1922-1972 gg. Iubileinyi statisticheskii ezhegodnik. Moscow: Statistika. (translated into English and reprinted as: Selected statistics from the national economy of the USSR, 1922-1972, Soviet Education, September-October 1974, (pp. 79-141).

Suddaby, A. (1989). An evaluation of the contribution of the teacher innovators to Soviet educational reform. Comparative Education, 25(2), 245-256.

Sutherland, J. (1999). Schooling in the new Russia: Innovation \& change, 1984-95. London: Macmillan \& St. Martin Press.

Tillett, L. (1969). The great friendship: Soviet historians on the non-Russian nationalities. Chapel Hill, NC: University of North Carolina Press.

US Department of State (USDoS). (1996). Tajikistan: Country report on economic policy and trade practices. US Department of State report submitted to the Senate Committees on Foreign Relations.

UNDP. (2000). Tajikistan national human development report: 2000. Retrieved April 23, 2003, from http://www.undp.tj/Publications/nhdr2000.pdf

UNESCO. (1999). The EFA 2000 assessment country report: Tajikistan. Report submitted by Tajikistan Government. Retrieved December 16, 2003, from www.unesco.org

World Bank (WB). (1999). Project appraisal document on a proposed learning and innovation credit to the Republic of Tajikistan for an education reform project. Washington, DC: The World Bank.

World Bank (WB). (2003). Tajikistan - education modernization project appraisal document. Retrieved December 1, 2003 from www.worldbank.org/servlet

Sarfaroz Niyozov, OISE, University of Toronto, Canada

\&

Stephen Bahry, University of Toronto, Canada 